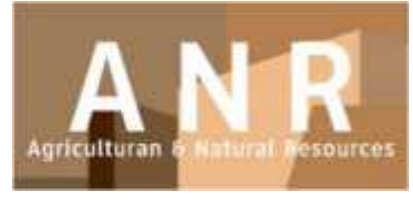

PAPER - OPEN ACCESS

\title{
Strategi Petani Sutera dalam Memenuhi Kebutuhan Rumah Tangga di Kabupaten Soppeng Sulawesi Selatan
}

\author{
Author : Nurhaedah Muin dan Wahyudi Isnan \\ DOI $\quad: 10.32734 /$ anr.v2i1.570 \\ Electronic ISSN : :2654-7023 \\ Print ISSN : :2654-7015
}

Volume 2 Issue 1 - 2019 TALENTA Conference Series: Agricultural and Natural Resources (ANR)

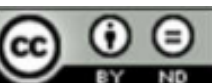

This work is licensed under a Creative Commons Attribution-NoDerivatives 4.0 International License.

Published under licence by TALENTA Publisher, Universitas Sumatera Utara

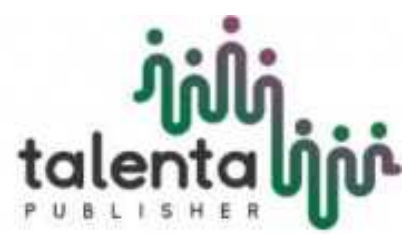




\title{
jiditi

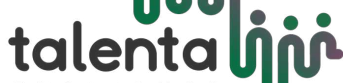 \\ ANR Conference Series 02 (2019) \\ TALENTA Conference Series
}

Available online at https://talentaconfseries.usu.ac.id

\section{Strategi Petani Sutera dalam Memenuhi Kebutuhan Rumah Tangga di Kabupaten Soppeng Sulawesi Selatan}

(The Strategy of Silk Farmers in achieving Household Needs in Soppeng District, South Sulawesi)

\author{
Nurhaedah Muin ${ }^{1 *}$ dan Wahyudi Isnan ${ }^{1}$ \\ Balai Penelitian dan Pengembangan Lingkungan Hidup dan Kehutanan, Makassar \\ Jl. Perintis Kemerdekaan km 16 Makassar, 90243, \\ telp. (0411) 554048, fax. (0411) 554058
}

Email: nurhaedah_muin@yahoo.com, yudix_19@yahoo.com

\begin{abstract}
Abstrak
Usaha sutera alam pada aspek hulu menghasilkan produk berupa kokon ataupun benang. Produksi kokon ulat sutera petani sangat dipengaruhi oleh banyak faktor antar lain cuaca, ketersediaan pakan ulat sutera, bibit ulat sutera yang bermutu, tenaga kerja dan ruang budidaya yang memenuhi agar mampu menghasilkan kokon yang optimal. Beragamnya faktor pendukung berdampak pada ketidakpastian penghasilan dalam memenuhi kebutuhan rumah tangga sehingga diperlukan strategi dalam memenuhi kebutuhan hidup. Memberikan informasi mengenai strategi penghidupan petani sutera dalam memenuhi kebutuhan hidup yang bermanfaat dalam pengambilan kebijakan pengembangan persuteraan alam merupakan fokus dari tulisan ini. Penelitian dilakukan di Desa Sering, Kecamatan Donri-Donri Kabupaten Soppeng, Provinsi Sulawesi Selatan. Observasi dan wawancara dilakukan terhadap petani sutera untuk mengumpulkan informasi yang selanjutnya dianalisis secara deskriptif kualitatif. Melalui wawancara diperoleh informasi bahwa pendapatan petani sutera berasal dari penjualan kokon ataupun benang sutera. Pemenuhan kebutuhan pangan (makanan pokok dan air) dan non pangan (energi, air, pendidikan dan kesehatan) dilakukan melalui strategi on farm dan non farm serta mengoptimalkan bantuan dari pemerintah. Untuk itu, diperlukan kegiatan pemberdayaan masyarakat agar kesejahteraan petani sutera dapat lebih meningkat.
\end{abstract}

Kata Kunci: petani sutera, strategi, rumah tangga, Kabupaten Soppeng

\begin{abstract}
Silk cultivation in the upstream aspect produces products in the form of cocoons or silk fiber. The production of silkworm cocoon farmers is highly influenced by many factors, including weather, availability of silkworm feed, quality silkworm seedlings, labor and cultivation space that meet the ability to produce an optimal cocoon. The variety of supporting factors has an impact on income uncertainty in meeting household needs so that a strategy is needed to fulfill life needs. This paper aims to provide information on the strategies for the livelihoods of silk farmers in fulfilling life needs that are useful in policy making for natural female development. The research was conducted in Sering Village, Donri-Donri Sub-District, Soppeng District, South Sulawesi Province. Observations and interviews were conducted on silk farmers to gather information which was then analyzed descriptively qualitatively. Through interviews, information was obtained that the income of silk farmers came from the sale of cocoons or silk thread. Fulfilling food (staple and water) and non-food needs (energy, water, education, and health) are carried out through on-farm and non-farm strategies and optimizing government assistance. For this reason, community empowerment activities are needed so that the welfare of silk farmers can be improved.
\end{abstract}

Keywords: farmer, strategy, household, Soppeng Regency

(C) 2019 The Authors. Published by TALENTA Publisher Universitas Sumatera Utara

Selection and peer-review under responsibility of Pertemuan Ilmiah Tahunan (PIT) dan Seminar Nasional Ke-4,

Komunitas Manajemen Hutan Indonesia (KOMHINDO)

p-ISSN: 2654-7015, e-ISSN: 2654-7023, DOI: 10.32734/anr.v2i1.570 


\section{Pendahuluan}

Kebutuhan masyarakat yang semakin beragam memerlukan usaha berupa mata pencaharian yang berkelanjutan agar dapat memenuhi berbagai kebutuhan rumah tangga. Kebutuhan masyarakat berbeda pada setiap rumah tangga dan wilayah serta dapat dipengaruhi oleh faktor lingkungan, pendidikan, pendapatan dan gaya hidup [3]. Pemenuhan kebutuhan rumah tangga mendorong masyarakat untuk memilih sumber matapencaharian yang sesuai sumberdaya daya manusia maupun sumberdaya alam yang dimiliki serta dipandang dapat memberi penghasilan berkelanjutan.

Di Kecamatan Donri-Donri Kabupaten Soppeng terdapat satu wilayah yaitu Desa Sering, yang saat ini sebagian warganya masih aktif dalam usaha budidaya murbei dan ulat sutera. Kondisi wilayah merupakan lahan kering didominasi tanaman jati merupakan tanaman jangka panjang mendorong masyarakat untuk mencari nafkah penghidupan untuk memenuhi kebutuhan jangka pendek dan jangka menengah. Umumnya petani melakukan kegiatan budidaya ulat sutera berkisar antara 6 sampai 10 kali/tahun. Jumlah periode pemeliharaan akan berdampak pada penghasilan rumah tangga petani sutera.

Persuteraan alam merupakan salah satu pilihan usaha yang dapat memberikan penghasilan dalam waktu kurang lebih sebulan. Kegiatan budidaya murbei dan budidaya ulat sutera yang dilakukan petani disertai faktor pendukung optimal dapat memberikan hasil kokon ataupun benang sutera dalam jangka waktu kurang lebih sebulan. Ketersediaan bibit ulat sutera dari produsen bibit pada awal dan pertengahan bulan memungkinkan petani dapat melakukan kegiatan budidaya ulat sutera secara kontinu. Namun, selain bibit ulat yang berkualitas juga masih perlu didukung oleh berbagai faktor pendukung lain seperti pakan, cuaca, tempat pemeliharaan ulat, alat pengokonan dan tenaga kerja untuk dapat memberikan produksi kokon yang optimal. Faktor-faktor tersebut saling terkait dan memengaruhi keberlangsungan budidaya murbei dan ulat sutera untuk menghasilkan kokon sebagai produk pada bagian hulu. Banyaknya faktor yang memengaruhi keberhasilan produksi kokon mengakibatkan operasional usaha ini tidak selalu dapat dilakukan sesuai dengan waktu yang dimiliki petani. Hal ini, berdampak pada keberlanjutan penghasilan yang diperoleh petani, sehingga dalam memenuhi kebutuhan primer sehari-hari maupun kebutuhan besar sewaktu-waktu seperti menyekolahkan anak, dibutuhkan strategi yang tepat.

Strategi penghidupan yang dilakukan oleh petani sutera untuk memenuhi kebutuhan rumah tangga dengan kondisi pendapatan yang tidak kontinu merupakan informasi yang menjadi fokus dari tulisan ini. Informasi ini diharapkan bermanfaat sebagai bahan dalam penyusunan kebijakan terkait upaya peningkatan kesejahteraan petani sutera khususnya di lokasi kajian.

\section{Metode Penelitian}

\subsection{Tempat dan Waktu}

Desa Sering, Kecamatan Donri-Donri Kabupaten Soppeng, Sulawesi Selatan merupakan tempat pelaksanaa penelitian pada tahun 2015. Berikut disajikan peta lokasi penelitian (Gbr 1). 


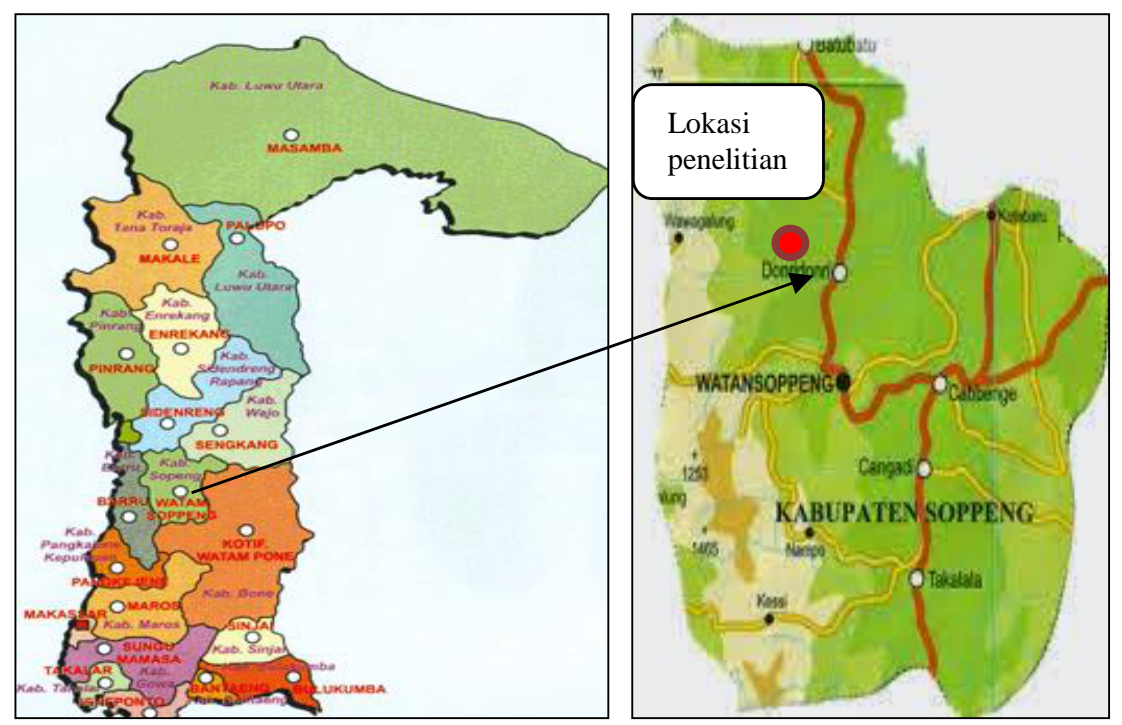

Gambar 1. Peta lokus penelitian (Sumber: http// google.co.id, 2018)

\subsection{Pengumpulan Data}

Interaksi langsung dengan responden melalui wawancara terbuka dilakukan untuk mendapatkan informasi yang mendalam tentang subjek yang diteliti. Selanjutnya study dokumentasi dilakukan untuk pencatatan data dan informasi di kantor-kantor yang ada kaitannya dengan penelitian 3.) Pengamatan langsung situasi dan kondisi faktual di lokasi penelitian dilakukan melalui observasi. Penentuan responden berdasarkan kriteria petani yang intensif melakukan budidaya murbei dan ulat sutera di Desa Sering.

\subsection{Analisis data}

Deskriptif kualitatif merupakan analisis yang digunakan untuk mengolah dan menganalisis data dan nformasi yang terkumpul menjadi data yang sistematik, teratur, terstruktur dan mempunyai makna sesuai topik penelitian.

\section{Hasil dan Pembahasan}

\subsection{Kondisi Geografi dan Demografi Wilayah Penelitian}

Desa Sering, Kecamatan Donri-Donri Kabupaten Soppeng merupakan salah satu daerah pengembangan usaha sutera alam. Hal ini ditunjang oleh keberdaan Desa Sering yang secara geografi terletak pada ketinggian 250 sampai 600 meter di atas permukaan laut dengan topografi datar, bergelombang dan berbukit. Jarak desa dari ibukota Kabupaten Soppeng adalah 14 km dengan posisi kurang lebih $12 \mathrm{~km}$ dari jalan poros Kabupaten Soppeng menunju Kabupaten Sidrap. Desa Sering memiliki luas wilayah $62 \mathrm{~km}^{2}$ dengan tanaman kehutanan utama jati lokal pada kelerengan 0-45\% [4]. Desa Sering berbatasan dengan Kecamatan Marioriawa pada sebelah utara, Sebelah timur berbatasan dengan Desa Lalabata Riaja dan Desa Donri-Donri, Desa Pesse pada sebelah selatan dan Kabupaten Barru pada sebelah barat.

Desa Sering terdiri 4 dusun, 9 RW dan 20 RT. Penggunaan lahan di Desa Sering sebagian besar adalah sawah, ladang, pekarangan, perkebunan, tanaman rumput dan hutan negara. Jumlah rumah tangga di Desa Sering sebanyak 466 dengan rata-rata jumlah anggota keluarga adalah 4 dari jumlah total penduduk desa sebesar 1.667 jiwa dengan orang [5]. Kelompok usia produktif dengan kisaran umur 50-54 tahun sebanyak 350 jiwa yang terdiri dari 159 jiwa laki-laki dan 191 jiwa perempuan mendominasi Desa Sering dibandingkan kelompok umur 0 - 4 tahun yaitu sebanyak 43 jiwa. Hal ini menggambarkan ketersediaan tenaga jumlah penduduk yang paling sedikit kerja produktif dalam melakukan aktivitas budidaya murbei dan ulat sutera. 
Kebutuhan pendidikan didukung oleh tersedianya fasilitas pendidikan meliputi SD Negeri 2 bh. SMP swasta 1 bh dan SMP Negeri 1 buah. Adapun fasilitas kesehatan yang ada di desa meliputi puskesmas pembantu 1 unit, poskesdes 3 unit disertai tenaga bidan desa 3 orang.

\subsection{Kondisi Sosial Ekonomi dan Budaya Masyarakat}

Petani merupakan mata pencaharian utama masyakat, selebihnya adalah non petani seperti tukang dan jasa pengangkutan. Jumlah kepala rumah tangga menurut mata pencaharian penduduk adalah petani $557 \mathrm{KK}$ ( 84,6\%), buruh $55 \mathrm{KK}(8,4 \%)$, pedagang $6 \mathrm{KK}(1 \%)$, guru $7 \mathrm{KK}(1 \%)$, tukang kayu $24 \mathrm{KK}(3,6 \%)$, pegangkutan 9 orang $(1,5 \%)[4]$.

Untuk kebutuhan konsumsi kebanyakan dipenuhi dari budidaya ulat sutera berupa penjualan kokon ulat sutera, hasil usaha tani lain dan penjualan ternak ayam kampung. Demikian pula untuk memenuhi sehari-hari lainnya diluar konsumsi (belanja perlengkapan cuci dan mandi, bayar listrik, pulsa, rokok dan bahan bakar untuk kendaraan motor). Untuk memenuhi kebutuhan besar sewaktu-waktu seperti menyekolahkan anak, hajatan berupa mengawinkan anak dan sunatan juga menggunakan komoditi sutera ditambah dengan hasil penjualan ternak.

Diversifikasi usahatani yang dilakukan petani sutera di lokasi meliputi tanaman pangan (jagung, padi, pepaya, pisang, mangga, kacang tanah dan buah naga) tanaman tahunan (kakao) dan usaha ternak ayam kampung dan sapi. Jagung biasanya ditanam satu kali setahun dan panen sekali setahun sedangkan kakao biasanya panen dilakukan setiap minggu hasilnya dikumpul lalu dijemur selanjutnya dijual di pasar kecamatan sehingga dapat memberikan pendapatan tambahan untuk memenuhi kebutuhan sehari-hari. Salah satu tujuan diversifikasi usahatani adalah untuk menstabilkan pendapatan petani [19]-[17].

Suku Bugis mendominasi penduduk Desa Sering yang umumnya beragama Islam. Bahasa Bugis merupakan bahasa pengantar sehari-hari yang kadang-kadang diselingi dengan Bahasa Indonesia dengan menyesuaikan situasi dan kondisi. Adat istiadat dan prilaku hidup masyarakat sangat diwarnai oleh budaya Suku Bugis. Penggunaan bahasa, model rumah, cara bercocok tanam, pengolahan makanan dan lain-lain menunjukkan prilaku hidup penduduk yang selalu berpedoman teguh pada nilai-nilai adat Bugis [15]-[2].

\subsection{Strategi Petani Sutera dalam Memenuhi Kebutuhan Rumah Tangga}

Usaha individu maupun kelompok sebagai upaya memenuhi keberlangsungan kehidupan tanpa mengabaikan eksistensi infrastruktur sosial, struktur sosial dan sistem nilai yang berlaku merupakan salah satu gambaran dari stategi nafkah [8].

Kebutuhan rumah tangga yang dimaksudkan dalam tulisan ini meliputi kebutuhan pangan (makanan pokok dan air) dan kebutuhan non pangan (energi, kesehatan, pendidikan).

- Strategi pemenuhan kebutuhan pangan (makanan pokok beserta pelengkapnya, air)

Pangan utama masyarakat di lokasi kajian berupa beras dan jagung. Masyarakat pembudidaya ulat sutera umumnya tidak memiliki lahan sawah, sehingga mereka memenuhi kebutuhan pangan beras dengan membeli beras dari hasil penjualan kokon ataupun benang sutera serta menggiling gabah yang diperoleh dari hasil upah panen padi di sekitar desa.

Pangan yang tercukupi secara kuantitas dan kualitas, aman dan halal, merata sesuai ruang dan waktu dan terjangkau baik individu maupun rumah tangga merupakan indikator terpenuhinya kebutuhan pangan rumah tangga[16]. Sedangkan penyediaan pangan yang terjangkau, kemudahan rumah tangga memperoleh bahan pangan dan / atau dengan harga yang terjangkau sesuai besaran penghasilan keluarga merupakan salah satu upaya untuk mewujudkan ketahanan pangan. Besaran pendapatan rumah tangga[3] dan tingkat pengetahuan terkait pangan dan gizi yang dapat memengaruhi pola konsumsi dan kecukupan pangan rumah tangga dapat memengaruhi distribusi 
pendapatan rumah tangga. Berikut kondisi pemenuhan pangan petani sutera di lokasi kajian (Tabel 1.)

\begin{tabular}{lll} 
& Tabel 1. Kondisi pemenuhan pangan petani sutera di Kabupaten Soppeng \\
\hline \multicolumn{1}{c}{ Variabel } & Kondisi & Strategi \\
\hline Jenis Makanan pokok & Beras, beras campur jagung & stok pangan, \\
Sumber perolehan & Kebun sendiri, beli di pasar & menanam tan.pangan \\
Konsumsi buah-buahan & Jarang (buah dari kebun sendiri) & menanam buah \\
Konsumsi daging & Jarang biasanya hari lebaran, & menyesuaikan kondisi \\
& acara hajatan & \\
Kekurangan pangan & Tidak pernah & menyesuaikan kondisi \\
\hline
\end{tabular}

Sumber: Data diolah, 2016.

Bahan makanan pokok berupa beras biasanya mereka stok pada saat memperoleh pendapatan berupa harga kokon ataupun benang yang optimal sesuai sumberdaya yang dimiliki. Saat budidaya ulat sutera yang dilakukan tidak mengalami serangan penyakit atau sebagaian besar ulat sutera mampu membentuk kokon merupakan kondisi panen yang optimal. Sebagian besar petani sutera khususnya di Desa Sering, Kecamatan Donri-Donri tidak memiliki sawah, sehingga membeli beras di pasar, sedangkan jagung biasanya diperoleh dari hasil kebun sendiri.. Adapun pemenuhan kebutuhan pangan seperti buah biasanya diperoleh dari kebun sendiri (pepaya, mangga) dan kadangkadang pemberian dari tetangga. Sedangkan konsumsi daging biasanya hanya diadakan pada hari lebaran atau ada hajatan, karena untuk konsumsi sehari-hari kebutuhan protein lebih banyak mengkonsumsi ikan. Meskipun demikian, mereka tidak pernah kekurangan pangan, karena warga menerima bantuan pemerintah berupa beras raskin yang dijatah $20 \mathrm{~kg} /$ bulan. Menurut [19] mengonsumsi bahan pangan produksi sendiri merupakan salah satu strategi petani pedesaan untuk memenuhi kebutuhan pangan rumah tangga. Hal ini terlihat nyata pada petani sutera dengan melakukan diversifikasi usahatani (Gbr 2.)

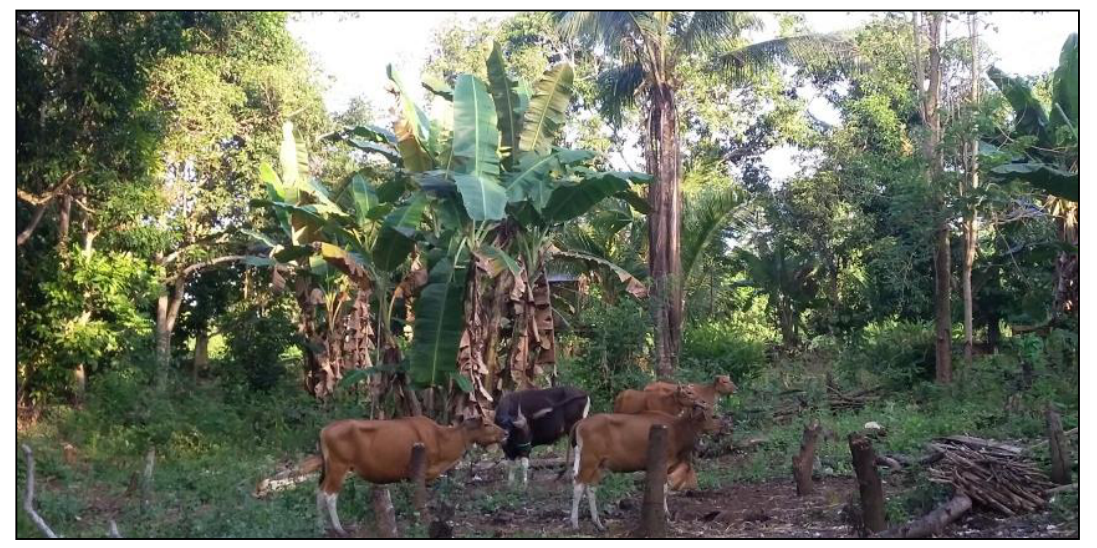

Gambar 2. Diversifikasi usaha tani yang dilakukan petani sutera (Sumber foto: koleksi penulis, 2017)

Selain diversifikasi usaha tani, petani sutera juga memanfaatkan waktu luang, jika tidak ada kegiatan budidaya ulat sutera dengan menjadi buruh tani secara musiman terutama saat musim panen padi di desa tetangga ataupun buruh angkat barang di pasar untuk memperoleh penghasilan tambahan dalam memenuhi kebutuhan rumah tangga.

Kebutuhan air terutama untuk MCK sebagian warga telah memiliki sumur galian ataupun sumur bor di rumah masing-masing. Namun, ketika musim kemarau tiba air sumur menjadi surut sehingga sebagian warga mengambil air di sumur tetangga terutama untuk kebutuhan memasak dengan menggunakan penampungan atau diangkut menggunakan jergen dengan menggunakan sepeda motor. Sedangkan untuk keperluan mandi dan mencuci sebagian warga yang tempat tinggalnya berdekatan dengan sungai memanfaatkan air sungai yang ada di Desa Sering. 
- Strategi petani sutera dalam memenuhi kebutuhan non pangan

Kebutuhan non pangan yang dimaksudkan adalah energi berupa kalor untuk mengolah makanan dan energi penerangan serta kebutuhan kesehatan dan pendidikan. Berikut disajikan kondisi pemenuhan kebutuhan non pangan petani sutera di Desa Sering (Tabel 2).

Tabel 2. Kondisi pemenuhan kebutuhan non pangan petani sutera di Desa Sering

\begin{tabular}{lll}
\hline \multicolumn{1}{c}{ Variabel kebutuhan } & Kondisi & Strategi \\
\hline Energi kalor untuk memasak & Kayu bakar, gas elpiji & Kombinasi keduanya \\
Energi penerangan & Listrik, lampu pelita & Menyesuaikan \\
Air & Sumur, sungai & Menyesuaikan \\
Kesehatan & Dokter puskesmas, orang pintar & Kombinasi \\
Pendidikan & TK, SD ,SMP & SMA di luar Desa \\
\hline
\end{tabular}

Sumber: Data diolah, 2016.

Energi kalor yang diperlukan untuk mengolah makanan umumnya menggunakan gas dan kayu bakar yang dikombinasi penggunaannya sesuai kondisi keuangan rumah tangga. Wilayah perkampungan yang didominasi hutan jati memungkinkan petani untuk memanfaatkan ranting-ranting kayu yang jatuh sebagai kayu energi. Untuk memasak air minum dan menanak nasi biasanya menggunakan kayu bakar. Beberapa faktor yang dapat memengaruhi konsumsi kayu bakar antara lain: jumlah penghasilan keluarga, tersedianya kayu bakar dengan harga terjangkau dan harga minyak tanah dan gas [1].

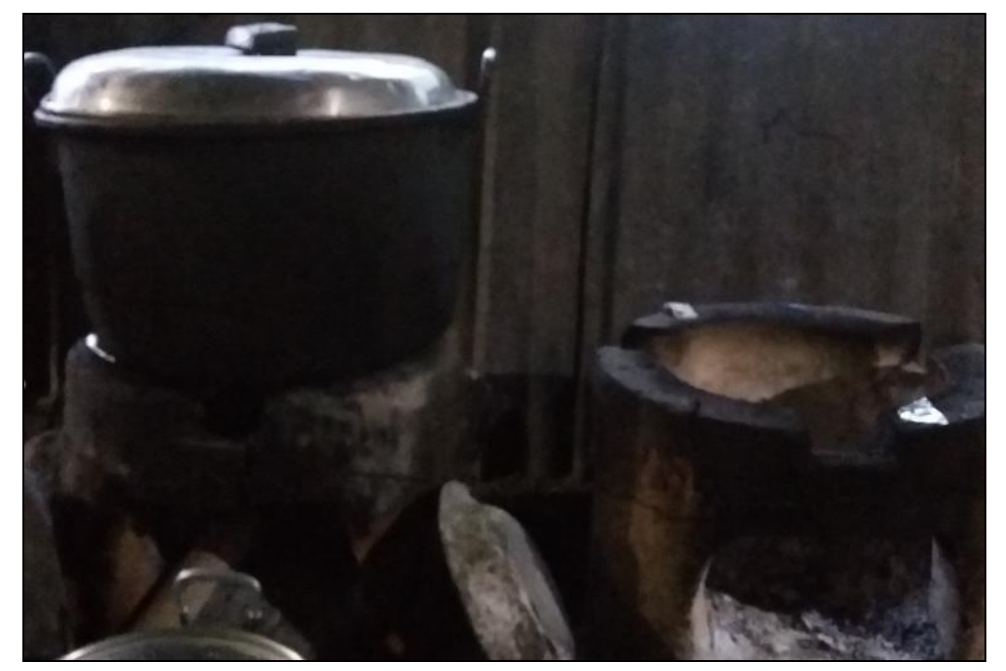

Gambar 3. Pemenuhan kebutuhan energi kalor menggunakan kayu bakar melalui tungku (Foto: Koleksi penulis, 2017)

Energi penerangan rumah tangga belum sepenuhnya menggunakan penerangan listrik elektrik PLN. Sebagian warga masih menggunakan penerangan lampu pelita berbahan minyak tanah yang dibeli dengan harga Rp.15.000/liter. Alasan responden adalah belum ada jaringan listrik dan kondisi pendanaan yang belum memadai untuk pemasangan listrik PLN.

Pemenuhan kebutuhan kesehatan di lokasi kajian dilakukan melalui kunjungan ke dokter praktek di Puskesmas Pembantu dan Puskesmas Kecamatan, pengobatan alami serta mendatangi orang pintar. Kondisi ini, tergantung pada kondisi ekonomi dan jenis penyakit yang diderita. Pada penyakit tertentu yang membutuhkan biaya besar dan tidak dapat dipenuhi dari penghasilan usaha sutera, kadang-kadang petani menjual ternaknya berupa sapi ataupun ternak lain yang dimiliki. Hal ini sejalan dengan hasil penelitian Ismail [10]-[9] bahwa faktor sosiodemografi seperti jumlah pendapatan, sosial budaya dan informasi dapat memengaruhi prilaku seseorang dalam melakukan 
pengobatan.

Untuk melanjutkan sekolah ke jenjang yang lebih tinggi sebagian warga menitipkan anaknya di rumah kerabat terdekat di ibukota kecamatan karena sarana pendidikan yang masih terbatas di desa serta jarak yang jauh antar rumah warga dengan sekolah. Pemenuhan kebutuhan belanja sehari-hari diluar pangan selain menggunakan penghasilan dari penjualan kokon ataupun benang sutera. Sebagian petani juga melakukan aktivitas sebagai pengumpul asam yang dipungut dari pohom asam yang ditanam di pinggir jalan Desa Sering. Asam jawa yang telah matang biasanya jatuh dan masyarakat memungut lalu dibuka kulitnya, selanjutnya dijemur dengan menggunakan sinar matahari langsung. Setelah melalui proses penjemuran, asam jawa dibentuk bundaran bulat lalu dipasarkan dengan harga 5000/bulatan. Pengawetan asam biasanya dilakukan dengan memberi garam dan pengasapan dengan cara menyimpan di atas tungku masak, agar asam tersebut tidak mudah rusak misalnya terserang jamur.

Secara umum petani sutera di Kabupaten Soppeng memiliki strategi penghidupan melalui on farm dan non farm, dimana on farm yaitu pendapatan yang diperoleh dari kegiatan usahatani sedangkan non farm melalui kegiatan non usahatani [7]. Hal ini dilakukan dengan mengoptimalkan sumberdaya yang dimiliki disertai usaha produktif sesuai potensi yang ada di wilayahnya. Selain itu, mereka melakukan strategi solidaritas horizontal dengan menjalin hubungan baik dengan tetangga [14]. Hal ini diperkuat oleh pernyataan [12] bahwa strategi penghidupan yang ditempuh petani tergantung kondisi sosio-ekologi dan sumberdaya yang dimiliki.

\section{Kesimpulan}

Pendapatan utama petani sutera berasal dari penjualan kokon dan benang sutera. Strategi petani sutera dalam memenuhi kebutuhan rumah tangga dengan mengoptimalkan pendapatan yang diperoleh disamping mengoptimalkan bantuan dari pemerintah. Untuk memperoleh tambahan penghasilan, petani melakukan diversifikasi usaha tani dan menjadi tenaga upahan musiman ketika tidak melakukan kegiatan budidaya ulat sutera, melalui kombinasi strategi on farm dan off farm serta membangun solidaritas dengan tetangga. Untuk itu, hubungan sosial masyarakat yang sudah berjalan perlu dipertahankan disertai upaya pemberdayaan petani sutera agar kapasitasnya dapat lebih meningkat dan mampu memenuhi kebutuhan rumah tangga yang berkelanjutan.

\section{Referensi}

[1] Astana, S.2012. "Konsumsi Kayu Bakar Rumah Tangga Pedesaan Dan Faktor-Faktor Yang Mempengaruhi Di Kabupaten Banjarnegara Jawa Tengah, Sukabumi Jawa Barat dan Lebak Banten”. Jurnal Penelitian Sosial dan Ekonomi Kehutanan 9 (4): 229 - 241.

[2] Abbas, I. 2013. Pappaseng: kearifan lokal manusia bugis yang terlupakan. Sosiohumaniora 15(3) : 272 - 284.

[3] Arida.A, Sofyan dan K. Fadhiela. 2015. "Analisis Ketahanan Pangan Rumah Tangga Berdasarkan Proporsi Pengeluaran Pangan Dan Konsumsi Energi (Studi Kasus Pada Rumah Tangga Petani Peserta Program Desa Mandiri Pangan di Kecamatan Indrapuri Kabupaten Aceh Besar)". Agrisep 16 (1) 2015.

[4] Badan Pusat Statistik. 2014. "Kecamatan Donri-Donri Dalam Angka”. Badan Pusat Statistik Kabupaten Soppeng.

[5] Badan Pusat Statistik. 2016. "Kecamatan Donri-Donri Dalam Angka”. Badan Pusat Statistik Kabupaten Soppeng

[6] Bara, C.O. 2013. "Kekuatan Produksi Pelaku Pemanenan Hutan Rakyat Kecamatan Donri-Donri- Kabupaten Soppeng”. Skripsi. Jurusan Kehutanan, Fakultas Kehutanan, Universitas Hasanuddin. Makassar.

[7] Budiyanti, I. 2017. "Strategi Nafkah dan Relasi Sosial Rumahtangga Petani Tebu (Studi Kasus: Desa Jenar, Kecamatan Jenar, Kabupaten Sragen)”. Skripsi. Fakultas Ekologi Manusia. Institut Pertanian Bogor.

[8] Dharmawan, A.H., 2007. "Sistem Penghidupan dan Nafkah Pedesaan: Pandangan Sosiologi Nafkah (Livelihood Sociology) Mahzab Barat dan Mahzab Bogor". Sodality Jurnal Sosiologi Pedesaan 1(2): 169-192.

[9] Gaol,T. L. 2013. "Pengaruh faktor sosiodemografi, sosioekonomi dan kebutuhan terhadap perilaku masyarakat dalam pencarian pengobatan di Kecamatan Medan Kota". Tesis. Fakultas Kesehatan Masyarakat Universitas Sumatera Utara.

[10] Ismail, 2015. "Faktor Yang Mempengaruhi Keputusan Masyarakat Memilih Obat Tradisional Di Gampong Lam Ujong”. Idea Nursing Journal VI (1): 7-14. ISSN: 2087-2879.

[11] Nurhaedah, H.Suryanto, A. Prasetyawati, N. Hayati. 2015. "Model Pengelolaan Persuteraan Alam". Laporan Hasil Penelitian. Balai Penelitian Kehutanan Makassar (tidak dipublikasi).

[12] Mualiana, W.A.2016. "Strategi livelihood rumah tangga petani padi sawah pada wilayah sekitar pertambangan emas (Studi Kasus di Desa Langkowala Kecamatan Lantari Jaya Kabupaten Bombana)”. Skripsi. Universitas Haluoleo. Kendari. 
[13] Oktavianti, H dan Zakik, 2017. "Perilaku Konsumsi Rumah Tangga Dan Pengaruhnya Terhadap Kebijakan Makro Ekonomi Kabupaten Bangkalan". Media Trend 12(1): 90-97.

[14] Rahmadi, F. 2016. "Nilai-nilai pendidikan dalam kehidupan bertetangga (Kajian kitab hadits Shahih Bukhari)”. Skripsi. Fakultas Tarbiyah dan Keguruan (FTK) Universitas Islam Negeri Ar-Raniry Darussalam - Banda Aceh.

[15] Said, Z. 2011. "Aksiologi budaya bugis makassar terhadap produk peraturan daerah (perda) di Sulawesi Selatan (Studi politik hukum)". Jurnal Hukum Diktum 9(1): 56-72.

[16] Soearmo, 2012. "Strategi pemenuhan kebutuhan pangan rumah -tangga pedesaan". Artikel. marno.lecture.ub.ac.id . Diakses 20 Nopember 2018.

[17] Susilowati, S.H. 2017. "Dinamika Diversifikasi Sumber Pendapatan Rumah Tangga Perdesaan di Berbagai Agroekosistem". Jurnal Agro Ekonomi 35 (2) Oktober 2017:105-126.

[18] Wardhani, A.T. 2017. "Dampak konsumsi hasil produksi sendiri (Own Produced Consumption) terhadap pola konsumsi pangan rumah tangga perdesaan”. Jurnal Ekonomi \& Kebijakan Publik, 8 (1) Juni 2017: 13 - 25.

[19] Wijayanti.P.U, dan W.S. Djelantik. 2016. "Tingkat Diversifikasi Usaha Tani di Daerah Hulu, Tengah, dan Hilir Daerah Irigasi Mambal”. E-Jurnal Agribisnis dan Agrowisata ISSN: 2301-6523 5 (2) April 2016. 